\title{
Perbandingan komplikasi antara fakoemulsifikasi dan manual small-incision cataract surgery (mSICS) pada operasi katarak massal: Sebuah penelitian kohort retrospektif
}

\author{
Tri Winarti, ${ }^{1,2 *}$ Indra Tri Mahayana, ${ }^{2}$ Reny Setyowati, ${ }^{2}$ Suhardjo Pawiroranu ${ }^{2}$ \\ ${ }^{1}$ Rumah Sakit Akademik Universitas Gadjah Mada, Yogyakarta, Indonesia \\ ${ }^{2}$ Departemen IImu Kesehatan Mata, Fakultas Kedokteran, Kesehatan Masyarakat, dan Keperawatan, \\ Universitas Gadjah Mada, Yogyakarta, Indonesia
}

\section{Submitted: 27 Desember 2019 Revised: 17 Februari 2019 Accepted: 21 Februari 2019}

\begin{abstract}
ABSTRAK Katarak adalah penyebab kebutaan reversible tertinggi dan kejadiannya semakin meningkat di komunitas seiring dengan bertambahnya usia. Fakoemulsifikasi dan manual small-incision cataract surgery (mSICS) merupakan teknik operasi katarak yang sering digunakan dalam program operasi katarak massal. Tujuan penelitian ini adalah untuk membandingkan komplikasi antara fakoemulsifikasi dan mSICS pada operasi katarak massal. Penelitian ini adalah penelitian kohort retrospektif dengan data diambil dari rekam medis program operasi katarak massal yang diselenggarakan oleh Divisi Oftalmologi Komunitas, Departemen IImu Kesehatan Mata, Fakultas Kedokteran, Kesehatan Masyarakat, dan Keperawatan (FKKMK), Universitas Gadjah Mada (UGM) pada Januari 2018 hingga November 2018. Operasi katarak dilakukan dengan teknik fakoemulsifikasi oleh dokter spesialis mata konsultan, dokter spesialis mata umum, dan residen mata senior, serta teknik mSICS oleh residen mata senior dan residen mata junior. Komplikasi intraoperatif dan pascaoperatif, misalnya robekan kapsul lensa posterior, prolaps vitreous, afakia, iridodialisis, endoftalmitis, yang terjadi hingga minggu keempat setelah operasi dibandingkan antara kedua teknik operasi tersebut. Sebanyak 483 pasien dioperasi, terdiri dari 188 (38,9\%) pasien yang dioperasi dengan teknik fakoemulsifikasi dan 295 (61,1\%) pasien yang dioperasi dengan teknik mSICS. Komplikasi intraoperatif dan pascaoperatif yang terjadi pada fakoemulsifikasi dan mSICS dengan operator residen mata senior tidak berbeda bermakna secara statistik $(p>0,05)$. Namun demikian, terdapat perbedaan yang bermakna antara jumlah komplikasi berupa robekan kapsul lensa posterior dan afakia pada fakoemulsifikasi, tingkat keterampilan operator yang berbeda $(p<0,05)$. Komplikasi tersebut paling banyak terjadi pada operasi yang dilakukan oleh residen mata senior yaitu sebanyak 11 (35,5\%) kasus dan $5(16,1 \%)$ kasus. Sebaliknya, komplikasi mSICS tidak berbeda bermakna secara statistik antara tingkat keterampilan operator yang berbeda, baik oleh residen mata senior maupun residen mata junior $(p>0,05)$. Komplikasi fakoemulsifikasi tidak berbeda bermakna dengan mSICS pada tingkat keterampilan operator yang sama (residen mata senior). Namun demikian, jumlah komplikasi robekan kapsul lensa posterior dan afakia pada teknik fakoemulsifikasi berbeda bermakna antara tingkat keterampilan operator.
\end{abstract}

KATA KUNCI fakoemulsifikasi; komplikasi; mSICS; operasi katarak massal

ABSTRACT Cataract is the most common cause of reversible blindness, and its prevalence have been increasing in the community depend on the age. Phacoemulsification and manual Small-Incision Cataract Surgery (mSICS) were the techniques of cataract surgery that was frequently used in high-volume cataract surgery setting. This study aimed to compare the complications between phacoemulsification and mSICS

\footnotetext{
*Corresponding author: Tri Winarti

Rumah Sakit Akademik Universitas Gadjah Mada, Jl. Kabupaten (Lingkar Utara), Kronggahan, Trihanggo, Yogyakarta 55291, Indonesia

E-mail: tri.winarti@mail.ugm.ac.id
} 
in high-volume cataract surgery. This research was a retrospective cohort study with the data taken from the medical record of high-volume cataract surgery organized by Community Ophthalmology Division, Department of Ophthalmology, Faculty of Medicine, Public Health, and Nursing, Universitas Gadjah Mada (UGM) from January 2018 to November 2018. Cataract surgery was performed by consultant ophthalmologists, general ophthalmologist, and senior ophthalmology resident for phacoemulsification and by senior ophthalmology resident and junior ophthalmology resident for mSICS. Intraoperative and postoperative complications (i.e. posterior capsule rupture, vitreous prolapse, aphakia, iridodialysis, endophthalmitis) until four weeks of follow up were compared in both techniques. There were 483 patients who had been operated, consist of 188 (38.9\%) patients underwent phacoemulsification and 295 (61.1\%) patients underwent mSICS. Intraoperative and postoperative complications in phacoemulsification and mSICS performed by senior ophthalmology resident were no statistically significant different $(p>0.05)$. Nevertheles, there was statistically significant different between the complication of posterior capsule rupture and aphakia in phacoemulsification based on the level of surgeon's skill $(p<0.05)$. Most of them performed by senior ophthalmology resident in 11 (35.5\%) cases and 5 (16.1\%) cases respectively. However, complications in mSICS were no significantly different between the level of surgeon's skill performed by senior ophthalmology resident and junior ophthalmology resident $(p>0.05)$. Complications in phacoemulsification and mSICS performed by senior ophthalmology resident with relatively similar in the level of surgeon's skill were not significantly different. However, the complication of posterior capsule rupture and aphakia in phacoemulsification was significantly different based on the level of surgeon's skill.

KEYWORDS phacoemulsification; complication; mSICS; mass cataract surgery

\section{Pendahuluan}

Kebutaan di dunia mencapai lebih dari 39 juta kasus, 19 juta kasus di antaranya disebabkan oleh katarak bilateral yang terkait usia. ${ }^{1}$ Prevalensi kebutaan di Indonesia merupakan yang tertinggi di Asia Tenggara, yaitu 1,5\% dengan 52,0\% dari jumlah tersebut $(0,8 \%)$ disebabkan oleh katarak. ${ }^{2}$ Prevalensi katarak di Yogyakarta bahkan melebihi prevalensi katarak secara nasional yaitu sebesar 2,0\%. ${ }^{3}$ Kasus-kasus katarak yang belum tertangani akibat rendahnya tingkat operasi katarak di Indonesia, ditambah dengan peningkatan kasus baru sebanyak 0,1\% (240.000 kasus baru) setiap tahun, menyebabkan terjadinya penumpukan kasus katarak yang dikenal sebagai backlog katarak. ${ }^{2}$ Layanan bakti sosial operasi katarak massal merupakan aspek yang penting untuk diadakan mengingat $90,0 \%$ penderita kebutaan berasal dari daerah miskin. ${ }^{2}$ Upaya pemberantasan buta katarak sudah seharusnya difokuskan pada komunitas kurang mampu.

Divisi Oftlamologi Komunitas, Departemen Ilmu Kesehatan Mata, Fakultas Kedokteran, Kesehatan Masyarakat, dan Keperawatan, Universitas
Gadjah Mada (UGM) rata-rata menyelenggarakan kegiatan operasi katarak massal 15 hingga 20 kali setiap tahun. ${ }^{4}$ Program tersebut, selain untuk menurunkan backlog katarak, juga dilakukan sebagai sarana pembelajaran bagi para residen mata dalam mencapai kompetensi bedah katarak. Tindakan operasi katarak yang dilakukan oleh residen mata mencapai $51,3 \%$ dari seluruh kasus operasi katarak massal dan selebihnya dilakukan oleh dokter spesialis mata. ${ }^{4}$ Teknik manual smallincision cataract surgery (mSICS) dipilih sebagai teknik operasi yang pertama kali dilakukan oleh residen mata karena teknik operasi ini relatif lebih mudah dilakukan, dengan masa pembelajaran yang lebih singkat. ${ }^{5}$

Teknik mSICS merupakan alternatif teknik operasi katarak fakoemulsifikasi dengan biaya lebih murah dalam segi harga dan perawatan peralatan, serta merupakan teknik operasi katarak yang lebih cepat dan lebih tepat dilakukan untuk katarak matur. ${ }^{6}$ Teknik mSICS dan fakoemulsifikasi pada operasi katarak massal telah dilaporkan sama efektifnya dalam rehabilitasi tajam penglihatan 
pada pasien-pasien katarak. Tidak ada perbedaan tajam penglihatan dan komplikasi yang terjadi hingga evaluasi minggu keempat setelah operasi katarak antara dokter spesialis mata sebagai operator fakoemulsifikasi dan residen mata sebagai operator mSICS. ${ }^{4}$ Komplikasi yang paling sering terjadi pada teknik operasi mSICS dan fakoemulsifikasi adalah afakia akibat robekan kapsul lensa posterior, masing-masing 2,7\% dan 0,7 $\%$ kasus. ${ }^{4}$ Intraocular lens (IOL) drop dan nukleus drop terjadi masing-masing sebanyak $0,2 \%$ kasus pada mSICS, sementara itu pada fakoemulsifikasi terjadi pada $0,2 \%$ dan $0,5 \%$ kasus. ${ }^{4}$ Iridodialisis terjadi pada $0,5 \%$ kasus dengan tindakan mSICS, namun tidak berbeda bermakna secara statistik bila dibandingkan dengan fakoemulsifikasi. ${ }^{4}$ Sementara itu edema kornea persisten terjadi pada $1,7 \%$ kasus dengan tindakan mSICS dan 1,0\% pada fakoemulsifikasi. ${ }^{4}$ Namun demikian, komplikasikomplikasi yang terjadi pada fakoemulsifikasi dan mSICS belum dijelaskan lebih rinci berdasarkan tingkat keterampilan masing-masing operator.

Tujuan umum penelitian ini adalah untuk membandingkan komplikasi antara fakoemulsifikasi dan mSICS pada operasi katarak massal. Tujuan khusus penelitian ini adalah untuk membandingkan komplikasi yang terjadi antara fakoemulsifikasi dan mSICS pada operasi katarak massal berdasarkan tingkat keterampilan masing-masing operator. Hasil penelitian dijadikan sebagai bahan evaluasi agar kegiatan operasi katarak massal selanjutnya dapat dilakukan berkelanjutan dengan tingkat komplikasi seminimal mungkin. Penelitian ini juga dapat digunakan sebagai bahan evaluasi dalam rangka pencapaian kompetensi tindakan bedah katarak yang efektif bagi residen.

\section{Metode}

Penelitian ini adalah penelitian kohort retrospektif dengan data yang diambil dari rekam medis program operasi katarak massal yang diselenggarakan oleh Divisi Oftalmologi Komunitas, Departemen Ilmu Kesehatan Mata, FK-KMK, UGM periode Januari 2018 hingga November 2018. Operasi katarak dilakukan di sepuluh rumah sakit yang bekerja sama dengan Divisi Oftalmologi Komunitas, Departemen Ilmu Kesehatan Mata, FK-KMK, UGM untuk kegiatan operasi katarak massal. Ethical clearance pada penelitian ini diterbitkan oleh Komisi Etik FKKMK, UGM.

Dalam program operasi katarak massal dilakukan anamnesis, pemeriksaan oftalmologis, pemberian penjelasan mengenai operasi katarak yang akan dilakukan, dan permintaan persetujuan tindakan operasi katarak secara lisan dan tertulis kepada pasien. Kriteria inklusi pada penelitian ini adalah pasien dewasa berusia lebih dari 18 tahun dengan katarak imatur, katarak matur, atau katarak hipermatur. Kriteria eksklusi pada penelitian ini adalah pasien yang tidak datang sesuai jadwal kontrol. Pasien dengan katarak komplikata, katarak traumatika, dan katarak dengan subluksasi lensa juga tidak diikutsertakan dalam penelitian ini karena membutuhkan keterampilan khusus dalam tatalaksananya dan untuk menghindari bias tingkat keterampilan operator terhadap komplikasi yang mungkin dapat terjadi. Sementara itu, untuk menghindari bias tajam penglihatan postoperasi, pasien dengan riwayat penyakit retina, glaukoma, saraf optik, dan kekeruhan kornea dieksklusi pada penelitian ini. Penghitungan besar sampel penelitian tidak dilakukan dan pemilihan subjek penelitian dilakukan secara konsekutif.

Pasien yang menjalani pemeriksaan oftalmologis diperiksa secara biometri menggunakan AL-100 Biometer (Tomey Co, Nagoya, Japan) untuk menghitung kekuatan lensa tanam atau intraocular lens (IOL). Operasi katarak dilakukan dengan teknik fakoemulsifikasi atau mSICS tergantung dari derajat kekeruhan lensa. Pasien yang dioperasi menggunakan teknik mSICS yaitu pasien dengan katarak derajat 5 berdasarkan klasifikasi Burrato, sedangkan pasien yang dioperasi dengan teknik fakoemulsifikasi yaitu pasien dengan katarak derajat 2 hingga derajat 4 berdasarkan klasifikasi Burrato. Hal tersebut dilakukan untuk menghindari bias komplikasi karena katarak derajat 5 berdasarkan klasifikasi Burrato mempunyai nukleus lensa yang sangat keras dan sangat berisiko memberika komplikasi, terutama robekan kapsul 
Tabel 1. Definisi operasional variabel yang diteliti pada subjek yang dioperasi menggunakan teknik fakoemulsifikasi dan mSICS beserta analisis statistik yang digunakan.

\begin{tabular}{|c|c|c|c|c|}
\hline Variabel & Definisi Operasional & Pemeriksaan/Klasifikasi & Skala & Analisis Statistik \\
\hline Usia & $\begin{array}{l}\text { Usia subjek penelitian saat } \\
\text { dilakukan operasi katarak }\end{array}$ & $\begin{array}{l}\text { Selisih tanggal, bulan, dan tahun saat } \\
\text { operasi dengan tanggal, bulan, dan } \\
\text { tahun lahir subjek penelitian }\end{array}$ & Numerik & $\begin{array}{l}\text { Uji t tidak } \\
\text { berpasangan/ } \\
\text { Mann-Whitney }\end{array}$ \\
\hline Jenis kelamin & Jenis kelamin subjek penelitian & Pria atau wanita & Nominal & $\begin{array}{l}\text { Uji Chi-Square/ } \\
\text { Uji Eksak Fischer }\end{array}$ \\
\hline $\begin{array}{l}\text { Lateralitas mata } \\
\text { yang dioperasi }\end{array}$ & $\begin{array}{l}\text { Sisi mata subjek penelitian } \\
\text { yang dioperasi katarak }\end{array}$ & Mata kanan atau mata kiri & Nominal & $\begin{array}{l}\text { Uji Chi-Square/ } \\
\text { Uji Eksak Fischer }\end{array}$ \\
\hline $\begin{array}{l}\text { Tajam penglihatan } \\
\text { preoperasi }\end{array}$ & $\begin{array}{l}\text { Tajam penglihatan subjek } \\
\text { penelitian sesaat sebelum } \\
\text { operasi katarak }\end{array}$ & $\begin{array}{l}\text { Diperiksa menggunakan pen light, jari } \\
\text { tangan, Snellen chart atau E chart. } \\
\text { Pemeriksaan menggunakan Snellen } \\
\text { chart atau E chart dilakukan pada } \\
\text { jarak periksa } 6 \text { meter. }\end{array}$ & Numerik & $\begin{array}{l}\text { Uji t tidak } \\
\text { berpasangan/ } \\
\text { Mann-Whitney }\end{array}$ \\
\hline $\begin{array}{l}\text { Tajam penglihatan } \\
\text { pascaoperasi }\end{array}$ & $\begin{array}{l}\text { Tajam penglihatan pada hari } \\
\text { kedua, kelima, dan minggu } \\
\text { keempat setelah operasi }\end{array}$ & $\begin{array}{l}\text { Diperiksa menggunakan pen light, jari } \\
\text { tangan, Snellen chart atau E chart. } \\
\text { Pemeriksaan menggunakan Snellen } \\
\text { chart atau E chart dilakukan pada } \\
\text { jarak periksa } 6 \text { meter. }\end{array}$ & Numerik & $\begin{array}{l}\text { Uji t tidak } \\
\text { berpasangan/ } \\
\text { Mann-Whitney }\end{array}$ \\
\hline
\end{tabular}

Tabel 2. Kriteria diagnostik komplikasi intraoperatif pada fakoemulsifikasi dan mSICS

\begin{tabular}{|c|c|c|c|c|}
\hline $\begin{array}{l}\text { Komplikasi } \\
\text { Intraoperatif }\end{array}$ & Definisi Operasional & Pemeriksaan/Penilaian & Skala & Analisis Statistik \\
\hline $\begin{array}{l}\text { Robekan kapsul } \\
\text { lensa posterior }\end{array}$ & $\begin{array}{l}\text { Diskontinuitas kapsul lensa } \\
\text { posterior }\end{array}$ & $\begin{array}{l}\text { Ada atau tidaknya robekan kapsul } \\
\text { lensa posterior saat operasi katarak } \\
\text { yang dinilai dengan mikroskop } \\
\text { operasi }\end{array}$ & Nominal & $\begin{array}{l}\text { Uji Chi-Square/ } \\
\text { Uji Eksak Fischer }\end{array}$ \\
\hline Prolaps vitreous & $\begin{array}{l}\text { Vitreous yang prolaps ke } \\
\text { dalam kapsul lensa, bilik mata, } \\
\text { atau ekstraokular }\end{array}$ & $\begin{array}{l}\text { Ada atau tidaknya prolaps } \\
\text { vitreous saat operasi katarak yang } \\
\text { dinilai dengan mikroskop operasi }\end{array}$ & Nominal & $\begin{array}{l}\text { Uji Chi-Square/ } \\
\text { Uji Eksak Fischer }\end{array}$ \\
\hline Afakia & $\begin{array}{l}\text { Kondisi di mana tidak terdapat } \\
\text { lensa tanam dalam kapsul } \\
\text { lensa (in the bag) atau dalam } \\
\text { sulkus (in the sulcus) }\end{array}$ & $\begin{array}{l}\text { Ada atau tidaknya kondisi afakia } \\
\text { saat operasi katarak }\end{array}$ & Nominal & $\begin{array}{l}\text { Uji Chi-Square/ } \\
\text { Uji Eksak Fischer }\end{array}$ \\
\hline Iridodialisis & $\begin{array}{l}\text { Kondisi di mana bagian } \\
\text { pangkal iris terlepas }\end{array}$ & $\begin{array}{l}\text { Ada atau tidaknya iridodialisis saat } \\
\text { operasi katarak yang dinilai dengan } \\
\text { mikroskop operasi }\end{array}$ & Nominal & $\begin{array}{l}\text { Uji Chi-Square/ } \\
\text { Uji Eksak Fischer }\end{array}$ \\
\hline Hifema & $\begin{array}{l}\text { Kondisi di mana terdapat } \\
\text { darah dalam bilik mata depan }\end{array}$ & $\begin{array}{l}\text { Ada atau tidaknya hifema saat } \\
\text { operasi katarak yang dinilai dengan } \\
\text { mikroskop operasi }\end{array}$ & Nominal & $\begin{array}{l}\text { Uji Chi-Square/ } \\
\text { Uji Eksak Fischer }\end{array}$ \\
\hline IOL drop & $\begin{array}{l}\text { Kondisi di mana lensa tanam } \\
\text { jatuh ke dalam vitreous }\end{array}$ & $\begin{array}{l}\text { Ada atau tidaknya IOL drop saat } \\
\text { operasi katarak yang dinilai dengan } \\
\text { mikroskop operasi }\end{array}$ & Nominal & $\begin{array}{l}\text { Uji Chi-Square/ } \\
\text { Uji Eksak Fischer }\end{array}$ \\
\hline Nukleus drop & $\begin{array}{l}\text { Kondisi di mana nukleus lensa } \\
\text { jatuh ke dalam vitreous }\end{array}$ & $\begin{array}{l}\text { Ada atau tidaknya nukleus drop } \\
\text { saat operasi katarak yang dinilai } \\
\text { dengan mikroskop operasi }\end{array}$ & Nominal & $\begin{array}{l}\text { Uji Chi-Square/ } \\
\text { Uji Eksak Fischer }\end{array}$ \\
\hline
\end{tabular}


Tabel 3. Kriteria diagnostik komplikasi pascaoperatif pada fakoemulsifikasi dan mSICS

\begin{tabular}{|c|c|c|c|c|}
\hline $\begin{array}{l}\text { Komplikasi } \\
\text { Postoperatif }\end{array}$ & Definisi Operasional & Pemeriksaan/Pengukuran & Skala & Analisis Statistik \\
\hline Uveitis anterior & Peradangan pada bilik mata depan & $\begin{array}{l}\text { Ada atau tidaknya uveitis } \\
\text { anterior yang dinilai dengan } \\
\text { lampu celah (slit lamp) }\end{array}$ & Nominal & $\begin{array}{l}\text { Uji Chi-Square/ } \\
\text { Uji Eksak Fischer }\end{array}$ \\
\hline Glaukoma sekunder & $\begin{array}{l}\text { Keadaan dimana tekanan bola } \\
\text { mata yang lebih tinggi dari } 21 \\
\text { mmHg karena penyebab yang } \\
\text { berkaitan dengan operasi katarak }\end{array}$ & $\begin{array}{l}\text { Ada atau tidaknya } \\
\text { glaukoma sekunder yang dinilai } \\
\text { dengan tonometer non kontak }\end{array}$ & Nominal & $\begin{array}{l}\text { Uji Chi-Square/ } \\
\text { Uji Eksak Fischer }\end{array}$ \\
\hline $\begin{array}{l}\text { Edema kornea } \\
\text { persisten }\end{array}$ & $\begin{array}{l}\text { Keadaan dimana bagian stroma } \\
\text { kornea memiliki kadar air } \\
\text { berlebihan akibat disfungsi atau } \\
\text { hilangnya sel endotel kornea yang } \\
\text { menyebabkan kornea tidak jernih } \\
\text { hingga minggu keempat setelah } \\
\text { operasi katarak }\end{array}$ & $\begin{array}{l}\text { Ada atau tidaknya edema } \\
\text { kornea persisten hingga minggu } \\
\text { keempat setelah operasi yang } \\
\text { dinilai dengan lampu celah (slit } \\
\text { lamp) }\end{array}$ & Nominal & $\begin{array}{l}\text { Uji Chi-Square/ } \\
\text { Uji Eksak Fischer }\end{array}$ \\
\hline Pupillary capture & $\begin{array}{l}\text { Keadaan dimana haptik lensa } \\
\text { tanam berada di bilik mata } \\
\text { belakang tetapi sebagian optik } \\
\text { lensa tanam terjepit oleh iris } \\
\text { sehingga berada di bilik mata } \\
\text { depan }\end{array}$ & $\begin{array}{l}\text { Ada atau tidaknya pupillary } \\
\text { capture setelah operasi katarak } \\
\text { yang dinilai dengan lampu celah } \\
\text { (slit lamp) }\end{array}$ & Nominal & $\begin{array}{l}\text { Uji Chi-Square/ } \\
\text { Uji Eksak Fischer }\end{array}$ \\
\hline $\begin{array}{l}\text { Haptik di bilik mata } \\
\text { depan }\end{array}$ & $\begin{array}{l}\text { Keadaan dimana haptik lensa } \\
\text { tanam berada di bilik mata depan }\end{array}$ & $\begin{array}{l}\text { Ada atau tidaknya haptik lensa } \\
\text { tanam yang berada di bilik mata } \\
\text { depan setelah operasi katarak } \\
\text { yang dinilai dengan lampu celah } \\
\text { (slit lamp) }\end{array}$ & Nominal & $\begin{array}{l}\text { Uji Chi-Square/ } \\
\text { Uji Eksak Fischer }\end{array}$ \\
\hline Sisa korteks lensa & $\begin{array}{l}\text { Keadaan dimana masih terdapat } \\
\text { sisa korteks lensa di intraokular }\end{array}$ & $\begin{array}{l}\text { Ada atau tidaknya sisa korteks } \\
\text { lensa setelah operasi katarak } \\
\text { yang dinilai dengan lampu celah } \\
\text { (slit lamp) }\end{array}$ & Nominal & $\begin{array}{l}\text { Uji Chi-Square/ } \\
\text { Uji Eksak Fischer }\end{array}$ \\
\hline $\begin{array}{l}\text { Desenterasi lensa } \\
\text { tanam }\end{array}$ & $\begin{array}{l}\text { Keadaaan dimana lensa tanam } \\
\text { bergeser dari posisi sentral }\end{array}$ & $\begin{array}{l}\text { Ada atau tidaknya desenterasi } \\
\text { lensa tanam setelah operasi } \\
\text { katarak yang dinilai dengan } \\
\text { lampu celah (slit lamp) }\end{array}$ & Nominal & $\begin{array}{l}\text { Uji Chi-Square/ } \\
\text { Uji Eksak Fischer }\end{array}$ \\
\hline Endoftalmitis & $\begin{array}{l}\text { Peradangan pada seluruh jaringan } \\
\text { intraokular }\end{array}$ & $\begin{array}{l}\text { Ada atau tidaknya peradangan } \\
\text { pada seluruh jaringan } \\
\text { intraokular setelah operasi } \\
\text { katarak yang dinilai dengan } \\
\text { lampu celah (slit lamp) dan USG } \\
\text { mata }\end{array}$ & Nominal & $\begin{array}{l}\text { Uji Chi-Square/ } \\
\text { Uji Eksak Fischer }\end{array}$ \\
\hline
\end{tabular}

lensa posterior, prolaps vitreous, dan afakia, jika dilakukan dengan teknik fakoemulsifikasi. ${ }^{6}$

Fakoemulsifikasi dilakukan oleh dokter spesialis mata konsultan, dokter spesialis mata umum, dan residen mata senior, sedangkan mSICS dilakukan oleh residen mata senior dan residen mata junior. Residen mata senior adalah residen mata yang minimum telah melakukan 40 operasi katarak dengan teknik mSICS dan telah lulus ujian operasi dengan teknik mSICS yang diselenggarakan oleh Departemen IImu Kesehatan Mata, FKKMK, UGM dan telah melakukan latihan operasi fakoemulsifikasi pada mata binatang, sedangkan residen mata junior adalah residen mata yang 
belum genap melakukan 40 operasi katarak dengan teknik mSICS dan belum menjalani ujian operasi dengan teknik mSICS.

Operasi katarak dilakukan dengan anestesi lokal menggunakan injeksi retrobulbar dengan lidokain 2 cc dan bupivacaine 2 cc. Pada fakoemulsifikasi, insisi kornea dilakukan di daerah temporal pada bagian limbus kornea dengan menggunakan pisau keratom 2,75 mm. Kapsulotomi dilakukan dengan teknik continous curvilinear capsulorrhexis (CCC). Fakoemulsifikasi dilakukan menggunakan mesin AMO Sovereign Compact Phacoemulsifier ${ }^{\circ}$ (Abbott Medical Optics Inc., California, Amerika Serikat). IOL yang digunakan adalah IOL foldable jenis hydrophilic foldable poly hydroxy ethyl methacrylate. Pada mSICS, insisi sklera dibuat 1,5 $\mathrm{mm}$ dari limbus kornea di bagian superior dengan sepertiga ketebalan sklera dan lebar 6,5-7,0 mm atau disesuaikan dengan ukuran nukleus lensa. Tunnel sklerokornea dibuat meluas sampai 1,0-1,5 $\mathrm{mm}$ clear cornea. Kapsulotomi dilakukan dengan teknik CCC dengan diameter 5,0-6,0 $\mathrm{mm}$ atau disesuaikan dengan ukuran nukleus lensa. IOL yang digunakan dalam mSICS adalah jenis poly methyl methacrylate (PMMA).

Pasien setelah operasi mendapatkan antibiotik per oral ciprofloksasin $500 \mathrm{mg}, 1$ tablet tiap 12 jam selama 2 hari, Polidemisin (dexamethasone sodium phosphate $1 \mathrm{mg}$, neomycin sulphate 3,5 $\mathrm{mg}$, polymixin B sulphate $6.000 \mathrm{IU}) 1$ tetes tiap 4 jam per hari hingga dua minggu setelah operasi, kemudian dosisnya diturunkan menjadi tiap 6 jam per hari hingga empat minggu setelah operasi. Evaluasi dilakukan pada hari kedua, kelima, dan minggu keempat setelah operasi katarak. Evaluasi yang dicatat adalah tajam penglihatan, komplikasi intraoperasi, dan komplikasi setelah operasi. Evaluasi tersebut dilakukan oleh residen mata yang tidak mengetahui kelompok mana subjek yang diperiksa sehingga bias pemeriksaan tidak terjadi. Tajam penglihatan pada minggu keempat setelah operasi katarak dikoreksi dengan kacamata dan dikelompokkan menjadi 6/18 - 6/6 (good vision), < $6 / 18$ - 6/60 (fair vision), <6/60 - 3/60 (bad vision), dan $<3 / 60$ (low vision). Komplikasi intraoperasi dan komplikasi pascaoperasi dibandingkan antara teknik fakoemulsifikasi dan mSICS serta antar operator pada masing-masing teknik operasi tersebut. Analisis data pada penelitian ini dilakukan dengan program statistik SPSS Statistics 22 (IBM, New York, Amerika Serikat). Jika nilai $p<0,05$ maka terdapat perbedaan yang bermakna secara statistik antara dua variabel yang diuji.

Analisis perbandingan komplikasi intraoperatif dan pascaoperatif fakoemulsifikasi berdasarkan kelompok operator dilakukan dengan uji ChiSquare atau uji Kolmogorov-Smirnov jika tidak memenuhi untuk dilakukan uji Chi-Square. Analisis perbandingan komplikasi intraoperatif dan pascaoperatif mSICS berdasarkan kelompok operator dan analisis perbandingan komplikasi intraoperatif dan pascaoperatif antara fakoemulsifikasi dan mSICS yang dilakukan oleh residen mata senior dianalisis menggunakan uji Chi-Square atau uji Eksak Fisher jika tidak memenuhi syarat untuk dilakukan uji Chi-Square. Definisi operasional variable yang diteliti beserta krtiteria diagnosis komplikasi intraoperatif dan pascaoperatif dipaparkan pada Tabel 1,2, dan 3.

\section{Hasil}

Sebanyak 483 pasien dioperasi terdiri dari 188 (38,9\%) pasien dioperasi dengan teknik fakoemulsifikasi dan $295(61,1 \%)$ pasien yang dioperasi dengan teknik mSICS. Rata-rata usia pasien adalah $64,2 \pm 10,9$ tahun dengan jumlah pasien pria sebanyak $266(55,1 \%)$ dan jumlah pasien wanita sebanyak 217 (44,9\%). Sebanyak 276 (57,1\%) kasus yang dioperasi adalah mata kanan dan 207 (42,9\%) kasus adalah mata kiri. Tabel 4 menunjukkan tidak ada perbedaan yang bermakna secara statistik antara usia, jenis kelamin, dan sisi mata yang dioperasi antara kelompok fakoemulsifikasi dan $\operatorname{mSICS}(p>0,05)$.

Tajam penglihatan pada hari kedua, kelima, dan minggu keempat pascaoperatif tanpa koreksi kacamata tidak berbeda bermakna antara kedua kelompok, tetapi berbeda bermakna secara statistik pada minggu keempat pascaoperatif setelah dikoreksi dengan kacamata $(p=0,017)$. Tajam 
Tabel 4. Perbandingan subjek penelitian antara kelompok fakoemulsifikasi dan mSICS

\begin{tabular}{lcccc}
\hline \multicolumn{1}{c}{ Variabel } & $\begin{array}{c}\text { Total } \\
(\mathbf{n}=\mathbf{4 8 3})\end{array}$ & $\begin{array}{c}\text { Fakoemulsifikasi } \\
(\mathbf{n}=\mathbf{1 8 8})\end{array}$ & $\begin{array}{c}\text { mSICS } \\
(\mathbf{n}=\mathbf{2 9 5})\end{array}$ & $\boldsymbol{p}$ \\
\hline $\begin{array}{l}\text { Usia, tahun } \pm \text { SD } \\
\text { Jenis kelamin, n (\%) }\end{array}$ & $64,2 \pm 10,9$ & $63,6 \pm 10,9$ & $64,6 \pm 11,0$ & 0,319 \\
$\quad$ Pria & $266(55,1)$ & $111(59,0)$ & $155(52,5)$ & \\
$\quad$ Wanita & $217(44,9)$ & $77(41,0)$ & $140(47,5)$ & \\
Mata yang dioperasi, n (\%) & & & 0,161 \\
$\quad$ Mata kanan & $276(57,1)$ & $101(53,7)$ & $175(59,3)$ & \\
$\quad$ Mata kiri & $207(42,9)$ & $87(46,3)$ & $120(40,7)$ & \\
\hline
\end{tabular}

mSICS: manual small-incision cataract surgery, SD: standar deviasi.

Tabel 5. Perbandingan tajam penglihatan preoperatif dan pascaoperatif antara fakoemulsifikasi dan mSICS

\begin{tabular}{|c|c|c|c|}
\hline Visus, median (jangkauan) & $\begin{array}{l}\text { Fakoemulsifikasi } \\
\qquad n=188\end{array}$ & $\begin{array}{l}\mathrm{mSICS} \\
\mathrm{n}=295\end{array}$ & $p$ \\
\hline Visus preoperasi, median (rentang) & $2 / 60(1 / 60-6 / 15)$ & LP (LP-1/300) & $<0,001$ \\
\hline \multicolumn{4}{|l|}{ Visus postoperasi } \\
\hline $\mathrm{H}+2$ hari, median (rentang) & $2 / 60(1 / 300-6 / 7,5)$ & $1 / 60(1 / 300-6 / 9)$ & 0,259 \\
\hline $\mathrm{H}+5$ hari, median (rentang) & $6 / 60(1 / 300-6 / 6)$ & $6 / 60(1 / 300-6 / 7,5)$ & 0,075 \\
\hline $\mathrm{H}+4$ minggu (UCVA), median (rentang) & $6 / 21(1 / 300-6 / 6)$ & $6 / 30(1 / 300-6 / 6)$ & 0,226 \\
\hline $6 / 18-6 / 6$ [good vision, $\mathrm{n}(\%)]$ & $64(34,0)$ & $96(32,5)$ & \\
\hline$<6 / 18-6 / 60$ [fair vision, $\mathrm{n}(\%)$ ] & $81(43,1)$ & $128(43,4)$ & \\
\hline$<6 / 60-3 / 60$ [bad vision, $\mathrm{n}(\%)]$ & $13(6,9)$ & $30(10,2)$ & \\
\hline$<3 / 60$ [low vision, $\mathrm{n}(\%)]$ & $30(16,0)$ & $41(13,9)$ & \\
\hline $\mathrm{H}+4$ minggu (BCVA), median (rentang) & $6 / 12(1 / 300-6 / 6)$ & $6 / 15(1 / 300-6 / 6)$ & 0,017 \\
\hline 6/18 - 6/6 [good vision, $\mathrm{n}(\%)]$ & $122(64,9)$ & $163(55,3)$ & \\
\hline$<6 / 18-6 / 60$ [fair vision, $\mathrm{n}(\%)]$ & $29(15,4)$ & $83(28,1)$ & \\
\hline$<6 / 60-3 / 60$ [bad vision, $\mathrm{n}(\%)]$ & $14(7,4)$ & $21(7,1)$ & \\
\hline$<3 / 60$ [low vision, $\mathrm{n}(\%)]$ & $23(12,2)$ & $28(9,5)$ & \\
\hline
\end{tabular}

UCVA : uncorrected visual acuity; BCVA : best corrected visual acuity; LP : light perception.

penglihatan kategori good vision pada minggu keempat pascaoperasi tanpa koreksi kacamata pada kelompok fakoemulsifikasi sebanyak $34,0 \%$, sedangkan pada kelompok mSICS sebanyak 32,5\%, dan meningkat menjadi $64,9 \%$ pada kelompok fakoemulsifikasi dan 55,3\% pada kelompok mSICS setelah koreksi kacamata (Tabel 5).

Robekan kapsul lensa posterior adalah komplikasi intraoperatif tertinggi baik pada fakoemulsifikasi [21 (11,2\%) kasus], maupun pada mSICS [53 (18,0\%) kasus], dan berbeda bermakna secara statistik antara kedua kelompok $(p=0,043)$. Prolaps vitreous merupakan komplikasi intraoperatif terbanyak kedua pada masing-masing kelompok yang terjadi pada $12(6,4 \%)$ kasus pada fakoemulsifikasi dan $50(17,0 \%)$ kasus pada mSICS, yang juga berbeda bermakna secara statistik antara kedua kelompok $(p=0,001)$. Sementara itu, afakia pada kelompok fakoemulsifikasi terjadi sebanyak $7(3,7 \%)$ kasus dan pada kelompok mSICS terjadi sebanyak $18(6,1 \%)$ kasus, namun tidak berbeda bermakna secara statistik antara kedua kelompok ( $p=0,250)$. Iridodialisis banyak terjadi pada kelompok mSICS yaitu sebanyak $2(7,1 \%)$ kasus, namun pada kelompok fakoemulsifikasi hanya terjadi pada $1(0,5 \%)$, dan berbeda bermakna secara statistik antara kedua kelompok tersebut ( $p$ $=0,001)$. Hifema, IOL drop, dan nukleus drop juga 
Tabel 6. Perbandingan komplikasi intraoperatif antara kelompok fakoemulsifikasi dengan kelompok mSICS

\begin{tabular}{lcccc}
\hline \multicolumn{1}{c}{ Komplikasi } & $\begin{array}{c}\text { Total } \\
(\mathbf{n}=\mathbf{4 8 3})\end{array}$ & $\begin{array}{c}\text { Fakoemulsifikasi } \\
(\mathbf{n}=\mathbf{1 8 8})\end{array}$ & $\begin{array}{c}\text { mSICS } \\
(\mathbf{n}=\mathbf{2 9 5})\end{array}$ & $\boldsymbol{p}$ \\
\hline PCR, $\mathrm{n}(\%)$ & $74(15,3)$ & $21(11,2)$ & $53(18,0)$ & 0,043 \\
Prolaps vitreous & $62(12,8)$ & $12(6,4)$ & $50(17,0)$ & 0,001 \\
Afakia, $\mathrm{n}(\%)$ & $25(5,2)$ & $7(3,7)$ & $18(6,1)$ & 0,250 \\
Iridodialisis, $\mathrm{n}(\%)$ & $22(4,6)$ & $1(0,5)$ & $21(7,1)$ & 0,001 \\
Hifema, $\mathrm{n}(\%)$ & $5(1,0)$ & $0(0,0)$ & $5(1,7)$ & 0,162 \\
IOL drop, $\mathrm{n}(\%)$ & $5(1,0)$ & $2(1,1)$ & $3(1,0)$ & 1,000 \\
Nukleus drop, $\mathrm{n}(\%)$ & $1(0,2)$ & $1(0,5)$ & $0(0,0)$ & 0,389 \\
\hline
\end{tabular}

mSICS: manual small-incision cataract surgery, PCR: posterior capsule rupture, IOL: intraocular lens

Tabel 7. Perbandingan komplikasi intraoperatif pada tindakan fakoemulsifikasi berdasarkan kelompok operator

\begin{tabular}{lccccc}
\hline \multicolumn{1}{c}{ Komplikasi } & $\begin{array}{c}\text { Total } \\
(\mathbf{n = 1 8 8 )}\end{array}$ & $\begin{array}{c}\text { SpM(K) } \\
(\mathbf{n}=\mathbf{7 1 )}\end{array}$ & $\begin{array}{c}\text { SpM } \\
(\mathbf{n}=\mathbf{8 6})\end{array}$ & $\begin{array}{c}\text { Residen Senior } \\
(\mathbf{n}=\mathbf{3 1 )}\end{array}$ & $\boldsymbol{p}$ \\
\hline PCR, n (\%) & $21(11,2)$ & $5(7,0)$ & $5(5,8)$ & $11(35,5)$ & 0,005 \\
Prolaps vitreous & $12(6,4)$ & $3(4,2)$ & $3(3,5)$ & $6(19,5)$ & 0,112 \\
Afakia, $\mathrm{n}(\%)$ & $7(3,7)$ & $1(1,4)$ & $1(1,2)$ & $5(16,1)$ & 0,025 \\
Iridodialisis, $\mathrm{n}(\%)$ & $1(0,5)$ & $0(0,0)$ & $1(1,2)$ & $0(0,0)$ & - \\
Hifema, $\mathrm{n}(\%)$ & $0(0,0)$ & $0(0,0)$ & $0(0,0)$ & $0(0,0)$ & - \\
IOL drop, $\mathrm{n}(\%)$ & $2(1,1)$ & $0(0,0)$ & $0(0,0)$ & $2(6,5)$ & 0,119 \\
Nukleus drop, $\mathrm{n}(\%)$ & $1(0,5)$ & $0(0,0)$ & $0(0,0)$ & $1(3,2)$ & - \\
\hline
\end{tabular}

PCR: posterior capsule rupture, IOL: intraocular lens; $\mathrm{SpM}(\mathrm{K})$ : dokter spesialis mata konsultan; $\mathrm{SpM}$ : dokter spesialis mata umum

Tabel 8. Perbandingan komplikasi intraoperatif pada tindakan mSICS berdasarkan kelompok operator

\begin{tabular}{lcccc}
\hline \multicolumn{1}{c}{ Komplikasi } & $\begin{array}{c}\text { Total } \\
(\mathbf{n = 2 9 5 )}\end{array}$ & $\begin{array}{c}\text { Residen Senior } \\
(\mathbf{n}=\mathbf{6 8})\end{array}$ & $\begin{array}{c}\text { Residen Junior } \\
(\mathbf{n = 2 2 7})\end{array}$ & $\mathbf{p}$ \\
\hline PCR, $\mathrm{n}(\%)$ & $53(18,0)$ & $12(17,6)$ & $41(18,1)$ & 0,938 \\
Prolaps vitreous & $50(17,0)$ & $12(17,6)$ & $38(16,7)$ & 0,834 \\
Afakia, $\mathrm{n}(\%)$ & $18(6,1)$ & $6(8,8)$ & $12(5,3)$ & 0,260 \\
Iridodialisis, $\mathrm{n}(\%)$ & $21(7,1)$ & $7(10,3)$ & $14(6,2)$ & 0,279 \\
Hifema, $\mathrm{n}(\%)$ & $5(1,7)$ & $3(4,4)$ & $2(0,9)$ & 0,081 \\
IOL drop, $\mathrm{n}(\%)$ & $3(1,0)$ & $0(0,0)$ & $3(1,3)$ & 1,000 \\
Nukleus drop, $\mathrm{n}(\%)$ & $0(0,0)$ & $0(0,0)$ & $0(0,0)$ & - \\
\hline
\end{tabular}

PCR: posterior capsule rupture, IOL: intraocular lens

merupakan komplikasi intraoperatif yang terjadi, namun tidak berbeda bermakna secara statistik antara kedua kelompok $(p>0,05)$ (Tabel 6).

Pada kelompok fakoemulsifikasi, sebanyak
$71(37,8 \%)$ mata dioperasi oleh dokter spesialis mata konsultan, $86(45,7 \%)$ mata dioperasi oleh dokter spesialis mata umum, dan 31 (16,5\%) mata dioperasi oleh residen mata senior. Komplikasi 
Tabel 9. Perbandingan komplikasi pascaoperatif antara kelompok fakoemulsifikasi dengan kelompok mSICS

\begin{tabular}{lcccc}
\hline \multicolumn{1}{c}{ Komplikasi } & $\begin{array}{c}\text { Total } \\
(\mathbf{n}=\mathbf{4 8 3})\end{array}$ & $\begin{array}{c}\text { Fakoemulsifikasi } \\
(\mathbf{n}=\mathbf{1 8 8})\end{array}$ & $\begin{array}{c}\text { mSICS } \\
(\mathbf{n}=\mathbf{2 9 5})\end{array}$ & $\boldsymbol{p}$ \\
\hline Uveitis anterior, $\mathrm{n}(\%)$ & $2(0,4)$ & $1(0,5)$ & $1(0,3)$ & 1,000 \\
Glaukoma sekunder, $\mathrm{n}(\%)$ & $2(0,7)$ & $1(0,5)$ & $3(1,0)$ & 1,000 \\
Edema kornea persisten, $\mathrm{n}(\%)$ & $10(2,1)$ & $2(1,1)$ & $8(13,1)$ & 0,329 \\
Pupillary capture, $\mathrm{n}(\%)$ & $2(0,4)$ & $0(0,0)$ & $2(0,7)$ & 0,524 \\
Haptik di BMD, $\mathrm{n}(\%)$ & $3(0,6)$ & $0(0,0)$ & $3(1,0)$ & 0,285 \\
Sisa korteks lensa & $17(3,5)$ & $4(2,1)$ & $13(4,4)$ & 0,185 \\
Desenterasi IOL & $8(1,7)$ & $3(1,6)$ & $5(1,7)$ & 1,000 \\
Endoftalmitis, $\mathrm{n}(\%)$ & $1(0,2)$ & $1(0,5)$ & $0(0,0)$ & 0,389 \\
\hline
\end{tabular}

mSICS: manual small-incision cataract surgery, BMD : bilik mata depan, IOL: intraocular lens

Tabel 10. Perbandingan komplikasi pascaoperatif pada tindakan fakoemulsifikasi berdasarkan kelompok operator

\begin{tabular}{|c|c|c|c|c|c|}
\hline Komplikasi & $\begin{array}{c}\text { Total } \\
(\mathrm{n}=188)\end{array}$ & $\begin{array}{l}\mathrm{SpM}(\mathrm{K}) \\
(\mathrm{n}=71)\end{array}$ & $\begin{array}{c}\mathrm{SpM} \\
(\mathrm{n}=86)\end{array}$ & $\begin{array}{l}\text { Residen Senior } \\
\quad(\mathrm{n}=\mathbf{3 1})\end{array}$ & $p$ \\
\hline Uveitis anterior, n (\%) & $1(0,5)$ & $0(0,0)$ & $1(1,2)$ & $0(0,0)$ & - \\
\hline Glaukoma sekunder, n (\%) & $1(0,5)$ & $3(4,2)$ & $3(3,5)$ & $1(3,2)$ & 0,935 \\
\hline $\begin{array}{l}\text { Edema kornea persisten, } \mathrm{n} \\
\text { (\%) }\end{array}$ & $2(1,1)$ & $1(1,4)$ & $1(1,2)$ & $0(0,0)$ & 1,000 \\
\hline Pupillary capture, n (\%) & $0(0,0)$ & $0(0,0)$ & $0(0,0)$ & $0(0,0)$ & - \\
\hline Haptik di BMD, n (\%) & $0(0,0)$ & $0(0,0)$ & $0(0,0)$ & $0(0,0)$ & - \\
\hline Sisa korteks lensa & $4(2,1)$ & $0(0,0)$ & $1(1,2)$ & $3(9,7)$ & 0,122 \\
\hline Desenterasi IOL, n (\%) & $3(1,6)$ & $1(1,4)$ & $2(2,3)$ & $0(0,0)$ & 1,000 \\
\hline Endoftalmitis, n (\%) & $1(0,5)$ & $0(0,0)$ & $0(0,0)$ & $1(3,2)$ & - \\
\hline
\end{tabular}

BMD: Bilik Mata Depan, IOL: Intra ocular lens; SpM(K): dokter spesialis mata konsultan; SpM: dokter spesialis mata umum

intraoperatif robekan kapsul lensa posterior dan afakia berbeda bermakna secara statistik antara masing-masing operator fakoemulsifikasi $(p=$ 0,$005 ; p=0,025$ ) (Tabel 7).

Pada kelompok mSICS sebanyak $68(23,1 \%)$ mata dioperasi oleh residen mata senior dan 227 $(77,0 \%)$ mata dioperasi oleh residen mata junior. Semua komplikasi intraoperatif pada kelompok mSICS tidak berbeda bermakna secara statistik antara residen mata senior dan residen mata junior $(p>0,05)$ (Tabel 8).

Sisa korteks lensa adalah komplikasi pascaoperatif tertinggi, baik pada fakoemulsifikasi, [4 (2,1\%) kasus], maupun pada mSICS $[13(4,4 \%)$ kasus], namun tidak berbeda bermakna secara statistik $(p=0,185)$. Komplikasi pascaoperatif lain yang terjadi adalah uveitis anterior, glaukoma sekunder, edema kornea persisten, pupillary capture, haptik di bilik mata depan (BMD), sisa korteks lensa, desenterasi IOL, dan endoftalmitis, namun tidak berbeda bermakna secara statistik antara kedua kelompok $(p>0,05)$ (Tabel 9).

Semua komplikasi pascaoperatif pada kelompok fakoemulsifikasi tidak berbeda bermakna secara statistik antara kelompok dokter spesialis mata konsultan, dokter spesialis mata umum, dan residen mata senior $(p>0,05)$. Komplikasi yang terjadi pada fakoemulsifikasi adalah uveitis anterior, 
Tabel 11. Perbandingan komplikasi pascaoperatif pada tindakan mSICS berdasarkan kelompok operator

\begin{tabular}{lcccc}
\hline \multicolumn{1}{c}{ Komplikasi } & $\begin{array}{c}\text { Total } \\
(\mathbf{n}=\mathbf{2 9 5})\end{array}$ & $\begin{array}{c}\text { Residen Mata Senior } \\
(\mathbf{n}=\mathbf{6 8})\end{array}$ & $\begin{array}{c}\text { Residen Mata Junior } \\
(\mathbf{n}=\mathbf{2 2 7})\end{array}$ & $\boldsymbol{p}$ \\
\hline Uveitis anterior, $\mathrm{n}(\%)$ & $1(0,3)$ & $0(0,0)$ & $1(0,4)$ & 1,000 \\
Glaukoma sekunder, $\mathrm{n}(\%)$ & $3(1,0)$ & $2(2,9)$ & $1(0,4)$ & 0,132 \\
Edema kornea persisten, & $8(13,1)$ & $0(0,0)$ & $8(3,5)$ & 0,205 \\
$\mathrm{n}(\%)$ & & & & \\
Pupillary capture, $\mathrm{n}(\%)$ & $2(0,7)$ & $0(0,0)$ & $2(0,9)$ & 1,000 \\
Haptik di BMD, $\mathrm{n}(\%)$ & $3(1,0)$ & $1(1,5)$ & $2(0,9)$ & 0,542 \\
Sisa korteks lensa & $13(4,4)$ & $2(2,9)$ & $11(4,8)$ & 0,739 \\
Desenterasi IOL & $5(1,7)$ & $1(1,5)$ & $4(1,8)$ & 1,000 \\
Endoftalmitis, $\mathrm{n}(\%)$ & $0(0,0)$ & $0(0,0)$ & $0(0,0)$ & - \\
\hline
\end{tabular}

BMD : Bilik Mata Depan, IOL: Intra ocular lens

Tabel 12. Perbandingan komplikasi intraoperatif antara kelompok fakoemulsifikasi dengan kelompok mSICS, dengan operator residen mata senior

\begin{tabular}{lcccc}
\hline \multicolumn{1}{c}{ Komplikasi } & $\begin{array}{c}\text { Total } \\
(\mathbf{n = 9 9 )}\end{array}$ & $\begin{array}{c}\text { Fakoemulsifikasi } \\
\text { (n=21) }\end{array}$ & $\begin{array}{c}\text { mSICS } \\
\text { (n= 68) }\end{array}$ & $\boldsymbol{p}$ \\
\hline PCR, $\mathrm{n}(\%)$ & $23(23,2)$ & $11(52,4)$ & $12(17,6)$ & 0,051 \\
Prolaps vitreous & $18(18,2)$ & $6(28,6)$ & $12(17,6)$ & 0,838 \\
Afakia, $\mathrm{n}(\%)$ & $11(11,1)$ & $5(23,8)$ & $6(8,8)$ & 0,313 \\
Iridodialisis, $\mathrm{n}(\%)$ & $7(7,1)$ & $0(0,0)$ & $7(10,3)$ & 0,095 \\
Hifema, $\mathrm{n}(\%)$ & $3(3,0)$ & $0(0,0)$ & $3(4,4)$ & 0,550 \\
IOL drop, $\mathrm{n}(\%)$ & $2(2,0)$ & $2(9,5)$ & $0(0,0)$ & 0,096 \\
Nukleus drop, $\mathrm{n}(\%)$ & $1(1,0)$ & $1(4,8)$ & $0(0,0)$ & 0,313 \\
\hline
\end{tabular}

mSICS: manual small-incision cataract surgery, PCR: posterior capsule rupture, IOL: intraocular lens

Tabel 13. Perbandingan komplikasi pascaoperatif antara kelompok fakoemulsifikasi dengan kelompok mSICS dengan operator residen mata senior

\begin{tabular}{lcccc}
\hline \multicolumn{1}{c}{ Komplikasi } & $\begin{array}{c}\text { Total } \\
(\mathbf{n}=\mathbf{9 9 )}\end{array}$ & $\begin{array}{c}\text { Fakoemulsifikasi } \\
(\mathbf{n}=\mathbf{2 1})\end{array}$ & $\begin{array}{c}\text { mSICS } \\
(\mathbf{n}=\mathbf{6 8})\end{array}$ & $\boldsymbol{p}$ \\
\hline Glaukoma sekunder, $\mathrm{n}(\%)$ & $3(3,0)$ & $1(4,8)$ & $2(2,9)$ & 1,000 \\
Haptik di BMD, $\mathrm{n}(\%)$ & $1(1,0)$ & $0(0,0)$ & $1(1,5)$ & 1,000 \\
Sisa korteks lensa & $5(5,1)$ & $3(14,3)$ & $2(2,9)$ & 0,175 \\
Desenterasi IOL & $1(1,0)$ & $0(0,0)$ & $1(1,5)$ & 1,000 \\
Endoftalmitis, $\mathrm{n}(\%)$ & $1(1,0)$ & $1(4,8)$ & $0(0,0)$ & 0,313 \\
\hline
\end{tabular}

mSICS: manual small-incision cataract surgery, BMD : bilik mata depan, IOL: intraocular lens

glaukoma sekunder, edema kornea persisten, sisa korteks lensa, desenterasi IOL, dan endoftalmitis. Endoftalmitis terjadi pada satu kasus $(0,5 \%)$ dan dapat ditangani dengan baik (Tabel 10).
Semua komplikasi postoperasi pada kelompok mSICS tidak berbeda bermakna secara statistik antara residen mata senior dan residen mata junior $(p>0,05)$. Komplikasi yang terjadi pada mSICS 
antara lain uveitis anterior, glaukoma sekunder, edema kornea persisten, pupillary capture, haptik di BMD, sisa korteks lensa, dan desenterasi IOL. Endoftalmitis tidak terjadi pada teknik mSICS (Tabel 11).

Pada penelitian ini operator yang melakukan kedua teknik operasi hanyalah residen mata senior. Robekan kapsul lensa posterior adalah komplikasi intraoperatif tertinggi yang dilakukan oleh residen mata senior baik pada fakoemulsifikasi yaitu [11 $(52,4 \%)$ kasus], maupun pada mSICS $[12(17,6 \%)$ kasus], namun tidak berbeda bermakna secara statistik antara kedua kelompok $(p=0,051)$. Prolaps vitreous merupakan komplikasi intraoperatif terbanyak kedua pada masing-masing kelompok yang terjadi sebanyak $6(28,6 \%)$ kasus pada fakoemulsifikasi dan $12(17,6 \%)$ kasus pada mSICS yang juga tidak berbeda bermakna secara statistik antara kedua kelompok $(p=0,838)$. Sementara itu, afakia pada fakoemulsifikasi terjadi sebanyak $5(23,8 \%)$ kasus dan pada mSICS terjadi sebanyak $6(8,8 \%)$ kasus, namun tidak berbeda bermakna secara statistik antara kedua kelompok $(p=0,313)$. Iridodialisis dan hifema hanya terjadi pada mSICS yaitu sebanyak $7(10,3 \%)$ kasus dan $3(4,4 \%)$ kasus. Sementara itu, IOL drop dan nukleus drop hanya terjadi pada fakoemulsifikasi, yaitu sebanyak 2 $(9,5 \%)$ kasus dan $1(4,8 \%)$ kasus. Jumlah kasus iridodialisis, hifema, IOL drop, maupun nukleus drop tidak berbeda bermakna secara statistik antara kedua kelompok $(p>0,05)$ (Tabel 12).

Sisa korteks lensa adalah komplikasi pascaoperatif tertinggi yang dilakukan oleh residen mata senior baik pada fakoemulsifikasi $[3(14,3 \%)$ kasus], maupun pada mSICS [2 (2,9\%) kasus], namun tidak berbeda bermakna secara statistik ( $p$ $=0,175$ ). Komplikasi pascaoperatif lain yang terjadi antara lain glaukoma sekunder, haptik di BMD, desenterasi IOL, dan endoftalmitis, namun tidak berbeda bermakna secara statistik antara kedua kelompok $(p>0,05)$ (Tabel 13).

\section{Pembahasan}

Bakti sosial operasi katarak massal tentunya sangat membantu untuk menurunkan backlog katarak.
Walaupun dilakukan secara massal, kegiatan operasi katarak massal menggunakan tempat dan peralatan operasi yang sesuai dengan standar untuk operasi bedah intraokular, sehingga diharapkan dapat mendukung tercapainya hasil operasi yang optimal dan komplikasi seminimal mungkin.

Robekan kapsul lensa posterior adalah komplikasi intraoperatif tertinggi baik pada fakoemulsifikasi, [21 (11,2\%) kasus], maupun pada mSICS, [53 (18,0\%) kasus], dan berbeda bermakna secara statistik antara kedua kelompok $(p=0,043)$. Sementara itu, prolaps vitreous merupakan komplikasi intraoperatif terbanyak kedua pada masing-masing kelompok, $12(6,4 \%)$ kasus pada fakoemulsifikasi, dan 50 (17,0\%) kasus pada mSICS, yang juga berbeda bermakna secara statistik antara kedua kelompok $(p=0,001)$. Pada penelitian ini, komplikasi robekan kapsul lensa posterior berbeda bermakna secara statistik antar operator fakoemulsifikasi $(p=0,005)$ dan komplikasi tersebut paling banyak terjadi pada operator residen mata senior yaitu sebanyak $11(35,5 \%)$ kasus.

Penelitian lain melaporkan bahwa robekan kapsul lensa posterior dengan atau tanpa prolaps vitreous sebanyak $0,9 \%$ pada fakoemulsifikasi dan $0,6 \%$ pada mSICS. ${ }^{6}$ Rata-rata komplikasi intraoperatif lebih banyak terjadi sesuai dengan tingkat pengalaman operator, yaitu residen mata $2,1 \%$, fellow atau dokter spesialis mata umum $1,2 \%$, dan dokter spesialis mata konsultan $0,8 \%{ }^{6}$ Penelitian yang berbeda melaporkan bahwa prolaps vitreous dengan operator spesialis mata setidaknya terjadi pada 1000 kasus atau sebanyak 1,1-2,7\% kasus. ${ }^{6}$ Sementara itu, prolaps vitreous dengan operator residen mata terjadi antara 1,3-6,1\% kasus. ${ }^{6}$ Penelitian lainnya melaporkan kejadian prolaps vitreous terjadi sebanyak 3,5\% dari 45.082 pasien yang dioperasi katarak dan residen yang paling berkontribusi pada komplikasi tersebut. ${ }^{7}$ Hal tersebut menunjukkan bahwa keterampilan operator dan teknik operasi yang lebih sulit berpengaruh dalam kejadian komplikasi robekan kapsul posterior dan prolaps vitreous.

Robekan kapsul lensa posterior dan prolaps vitreous dapat dipengaruhi oleh kesempurnaan 
tahap kapsulotomi yang dilakukan oleh operator. Pada penelitian ini, kapsulotomi yang dilakukan adalah metode CCC dimana tahap tersebut membutuhkan kurva pembelajaran yang relatif lama. ${ }^{8}$ Selain itu, robekan kapsul lensa posterior dapat juga terjadi saat manipulasi ekstraksi lensa, terutama pada teknik fakoemulsifikasi. Pada teknik mSICS, operator terbanyak adalah residen mata junior yang melakukan operasi katarak sebanyak $227(77,0 \%)$ mata. Hal tersebut kemungkinan yang menyebabkan tingginya komplikasi robekan kapsul lensa posterior dan prolaps vitreous pada kelompok mSICS karena residen mata junior memiliki keterampilan yang relatif lebih rendah dibandingkan operator yang lain. Meskipun demikian, komplikasi robekan kapsul lensa posterior tidak berbeda bermakna secara statistik antar operator mSICS $(p>0,05)$ walaupun residen mata junior lebih banyak menyebabkan komplikasi tersebut, yaitu sebanyak $41(18,1 \%)$ kasus.

Pada penelitian ini, afakia yang terjadi pada fakoemulsifikasi yaitu sebanyak $7(3,7 \%)$ kasus dan pada mSICS sebanyak $18(6,1 \%)$ kasus, namun tidak berbeda bermakna secara statistik antara kedua kelompok $(p=0,250)$. Afakia berbeda bermakna secara statistik antar operator fakoemulsifikasi $(p$ $=0,025)$ dan komplikasi tersebut paling banyak terjadi pada operator residen mata senior, yaitu sebanyak 5 (16,1\%) kasus. Pada penelitian yang lain dilaporkan bahwa afakia terjadi pada 2,7\% kasus setelah dilakukan tindakan mSICS dan 0,7\% setelah dilakukan tindakan fakoemulsifikasi, namun juga tidak berbeda bermakna secara statistik antara kedua kelompok. ${ }^{4}$ Pada penelitian ini, afakia yang terjadi kemungkinan disebabkan karena robekan kapsul lensa posterior dan prolaps vitreous saat manipulasi ekstraksi lensa baik pada teknik fakoemulsifikasi maupun mSICS. Teknik ekstraksi lensa pada fakoemulsifikasi merupakan tahap operasi yang cukup sulit dan membutuhkan proses pembelajaran yang panjang sehingga pada penelitian ini afakia relatif lebih sering terjadi pada residen mata senior. Penelitian lain melaporkan bahwa mSICS membutuhkan proses pembelajaran yang lebih singkat dibandingkan fakoemulsifikasi. ${ }^{9}$
Oleh karena itu, residen mata junior pada penelitian ini hanya melakukan operasi dengan teknik mSICS untuk menghindari bias keterampilan operator pada komplikasi yang kemungkinan dapat terjadi.

Iridodialisis banyak terjadi pada mSICS yaitu sebanyak $21(7,1 \%)$ kasus, namun hanya terjadi pada $1(0,5 \%)$ kasus pada fakoemulsifikasi dan berbeda bermakna secara statistik antara kedua kelompok tersebut $(p=0,001)$. Pada penelitian lain dilaporkan bahwa iridodialisis adalah komplikasi intraoperatif yang cukup sering terjadi pada mSICS yaitu sebesar $0,5 \%$, walaupun tidak berbeda bermakna dengan fakoemulsifikasi. ${ }^{4}$ Kejadian iridodialis lebih sering terjadi pada mSICS dibanding fakoemulsifikasi karena massa lensa yang dikeluarkan pada teknik mSICS adalah massa utuh sehingga pada saat ekstraksi lensa dilakukan, sering kali massa lensa tersebut menekan dan menarik iris yang kemudian menyebabkan iridodialis. ${ }^{9}$

Hifema, IOL drop, dan nukleus drop juga merupakan komplikasi intraoperatif yang terjadi, namun tidak berbeda bermakna secara statistik antara kedua kelompok $(p>0,05)$. Pada penelitian lainnya dilaporkan bahwa IOL drop dan nukleus drop masing-masing terjadi pada $0,2 \%$ kasus setelah dilakukan tindakan mSICS, sementara itu IOL drop terjadi pada 0,2\% dan nukleus drop terjadi pada $0,5 \%$ kasus, pada fakoemulsifikasi, namun juga tidak berbeda bermakna secara statistik antara kedua kelompok. ${ }^{4}$ Sementara itu, semua komplikasi intraoperatif pada kelompok mSICS pada penelitian ini tidak berbeda bermakna secara statistik antara residen mata senior dan residen mata junior $(p>$ $0,05)$.

Sisa korteks lensa adalah komplikasi pascaoperatif terbanyak, baik pada fakoemulsifikasi, [4 (2,1\%) kasus], maupun pada mSICS [13 $(4,4 \%)$ kasus], namun tidak berbeda bermakna secara statistik $(p=0,185)$. Komplikasi pascaoperatif lain yang terjadi adalah uveitis anterior, glaukoma sekunder, edema kornea persisten, pupillary capture, haptik di BMD, desenterasi IOL, dan endoftalmitis, namun tidak berbeda bermakna secara statistik antara kedua kelompok $(p>0,05)$. Endoftalmitis terjadi pada satu kasus $(0,5 \%)$ pada 
fakoemulsifikasi dan dapat ditangani dengan baik. Penelitian lain melaporkan kejadian endoftalmitis dan komplikasi secara keseluruhan sangat rendah baik pada fakoemulsifikasi maupun pada mSICS, yaitu $0,0 \%$ kasus endoftalmitis dan 1,2\% kasus komplikasi intraoperatif. ${ }^{6}$ Penelitian lain juga melaporkan bahwa tidak terdapat perbedaan yang bermakna secara statistik pada komplikasi pascaoperatif antara fakoemulsifikasi dan $\mathrm{mSICS}^{4}{ }^{4}$

Semua komplikasi pascaoperatif pada kelompok fakoemulsifikasi tidak berbeda bermakna secara statistik antara dokter spesialis mata konsultan, dokter spesialis mata umum, dan residen mata senior $(p>0,05)$. Semua komplikasi pascaoperasi pada kelompok mSICS juga tidak berbeda bermakna secara statistik antara residen mata senior dan residen mata junior $(p>0,05)$. Komplikasi yang terjadi pada fakoemulsifikasi adalah uveitis anterior, glaukoma sekunder, edema kornea persisten, sisa korteks lensa, desenterasi IOL, dan endoftalmitis. Sementara itu, komplikasi yang terjadi pada mSICS adalah uveitis anterior, glaukoma sekunder, edema kornea persisten, pupillary capture, haptik di BMD, sisa korteks lensa, dan desenterasi IOL. Endoftalmitis tidak terjadi pada teknik mSICS. Penelitian lain menyebutkan bahwa edema kornea persisten terjadi pada 9 $(1,7 \%)$ kasus setelah dilakukan tindakan mSICS dan $5(1,0 \%)$ kasus setelah dilakukan tindakan fakoemulsifikasi dan tidak berbeda bermakna secara statistik antara kedua teknik operasi tersebut. ${ }^{4}$ Penelitian yang berbeda melaporkan bahwa teknik mSICS relatif sama dalam hal keamanan dibanding fakoemulsifikasi pada operator yang berpengalaman, tetapi mSICS lebih aman dibanding fakoemulsifikasi pada operator yang kurang berpengalaman. ${ }^{6}$

Kondisi tajam penglihatan preoperasi berbeda bermakna antara kelompok mSICS dan fakoemulsifikasi karena kelompok mSICS adalah kelompok dengan katarak derajat 5 yaitu katarak dengan nukleus lensa yang keras dan berwarna kecoklatan sehingga tentunya tajam penglihatan berbeda dibanding kelompok fakoemulsifikasi. Namun demikian, untuk meminimalisir adanya bias tajam penglihatan pascaoperatif, bias komplikasi yang kemungkinan dapat terjadi, dan bias tingkat keterampilan operator, katarak derajat 5 hanya dilakukan pada teknik mSICS. Hal tersebut dilakukan karena katarak derajat 5 memiliki nukleus lensa yang sudah keras dan jika dilakukan teknik fakoemulsifikasi akan lebih berisiko terjadinya komplikasi terutama jika dilakukan oleh operator yang kurang berpengalaman, misalnya terjadinya robekan kapsul lensa posterior, prolaps vitreous, dan afakia yang dapat berpengaruh pada tajam penglihatan pascaoperatif. Pada penelitian ini untuk menghindari bias tajam penglihatan pascaoperatif, pasien dengan penyakit retina, glaukoma, saraf optik, dan kekeruhan kornea juga tidak disertakan sebagai subjek penelitian.

Tajam penglihatan pada hari kedua, kelima, dan minggu keempat pascaoperatif tanpa koreksi kacamata tidak berbeda bermakna antara kedua kelompok, tetapi berbeda bermakna secara statistik pada minggu keempat pascaoperatif setelah dikoreksi dengan kacamata $(p=0,017)$. Tajam penglihatan kategori good vision pada minggu keempat pascaoperatif tanpa koreksi kacamata pada kelompok fakoemulsifikasi sebanyak 34,0\%, sedangkan pada kelompok mSICS sebanyak $32,5 \%$ dan meningkat menjadi $64,9 \%$ pada kelompok fakoemulsifikasi dan 55,3\% pada kelompok mSICS setelah koreksi kacamata.

Penelitian lain melaporkan bahwa tajam pengihatan $\geq 6 / 18$ tanpa koreksi kacamata pada evaluasi minggu keempat dengan teknik mSICS sebanyak $45,5 \%$ dan dengan koreksi kacamata meningkat menjadi 53,5\%, sedangkan pada fakoemulsifikasi sebanyak 52,4\% tanpa koreksi kacamata dan meningkat menjadi $59,6 \%$ dengan koreksi kacamata. Pada, penelitian tersebut tidak didapatkan perbedaan yang bermakna secara statistik baik tajam penglihatan tanpa koreksi kacamata dan dengan koreksi kacamata. ${ }^{4}$ Teknik mSICS dilaporkan dapat menyebabkan astigmatisme karena pembuatan tunnel sklerokornea yang cukup lebar, dengan rata-rata sekitar $6,5 \mathrm{~mm}$ yang menyebabkan tajam penglihatannya sedikit lebih rendah dibanding fakoemulsifikasi. ${ }^{10}$ Rata-rata 
astigmatisme yang diinduksi oleh fakoemulsifikasi adalah 0,8 $\pm 0,2$ dioptri dan astigmatisme yang diinduksi oleh mSICS adalah $1,2 \pm 0,4$ dioptri. ${ }^{1}$ Kondisi tajam penglihatan pada hari kedua, kelima, dan minggu keempat pascaoperatif tanpa koreksi kacamata pada penelitian ini tidak berbeda bermakna antara kedua kelompok, tetapi berbeda bermakna secara statistik pada minggu keempat pascaoperasi setelah dikoreksi dengan kacamata . Hal tersebut sangat mungkin terjadi karena kelainan refraksi akibat astigmatisme yang diinduksi oleh tunnel sklerokornea pada mSICS atau insisi kornea pada fakoemulsifikasi.

Keterbatasan penelitian ini adalah masingmasing operator, kecuali residen senior, tidak melakukan kedua teknik operasi sehingga kemungkinan terjadi bias perbandingan komplikasi operasi antara fakoemulsifikasi dan mSICS karena perbedaan tingkat keterampilan operator dan perbedaan tingkat kesulitan teknik operasi. Namun demikian, penelitian ini menunjukkan bahwa komplikasi operasi antara fakoemulsifikasi dan mSICS dengan operator yang sama, yaitu resien senior, tidak berbeda bermakna secara statistik. Selain itu, tidak disebutkan dengan rinci komplikasi intraoperatif terjadi pada tahapan apa saat operasi dilakukan. Pada penelitian selanjutnya perlu dilakukan analisis sesuai dengan tingkat keterampilan operator pada kedua teknik operasi sehingga didapatkan informasi mengenai hubungan antara tingkat keterampilan operator dengan hasil operasi yang didapat. Selain itu, perlu dilakukan pencatatan mengenai tahapan operasi yang menyebabkan komplikasi sehingga akan diketahui secara tepat, pada tahapan-tahapan operasi apa saja yang dapat menyebabkan komplikasi pada kedua teknik operasi. Hal tersebut akan sangat bermanfaat sebagai bahan evaluasi agar komplikasi yang terjadi lebih sedikit.

\section{Kesimpulan}

Komplikasi yang terjadi pada fakoemulsifikasi dan mSICS dengan operator residen mata senior tidak berbeda bermakna. Terdapat perbedaan komplikasi berupa robekan kapsul lensa posterior dan afakia yang bermakna pada fakoemulsifikasi berdasarkan tingkat keterampilan operator dengan kejadian paling banyak pascaoperasi oleh operator residen mata senior, sedangkan pada mSICS tidak terdapat perbedaan jumlah kasus komplikasi yang bermakna berdasarkan tingkat keterampilan operator, baik oleh residen mata senior maupun residen mata junior. Latihan operasi katarak pada mata binatang sebelum praktek langsung pada mata manusia dan pendampingan ketat pada tiap tahapan operasi oleh dokter senior yang kompeten melakukan fakoemulsifikasi dan mSICS sangat dibutuhkan untuk meminimalisir terjadinya komplikasi, serta untuk pencapaian kompetensi tindakan bedah katarak bagi residen.

\section{Konflik kepentingan}

Penulis menyatakan tidak ada konflik kepentingan dalam penelitian ini.

\section{Daftar pustaka}

1. Venkatesh R, Tan CSH, Sengupta S, Ravindran RD, Krishnan KT, Chang DT. Phacoemulsification versus small incision cataract surgery for white cataract. J Cataract Refract Surg. 2010;36:184954.

2. Persatuan Dokter Spesialis Mata Indonesia. Buku pedoman penyelenggaraan bakti sosial operasi katarak seksi penanggulangan buta katarak. Jakarta: Persatuan Dokter Spesialis Mata Indonesia; 2013.

3. Badan Penelitian dan Pengembangan Kesehatan Kementerian Kesehatan Republik Indonesia. Riset kesehatan dasar 2013. Jakarta: Kementerian Kesehatan Republik Indonesia; 2013.

4. Mahayana IT, Setyowati R, Hani SM, Winarti $\mathrm{T}$, Pawiroranu S. Outcomes of manual Small Incision Cataract Surgery (mSICS) compared with phacoemulsification from population based outreach eye camp, in Yogyakarta and Southern Central Java Region, Indonesia. J Community Empowerment for Health. 2018;1:1-6.

5. Gogate P. Comparison of various techniques for 
cataract surgery, their efficacy, safety and cost. Oman J Ophthalmol. 2010;3(3):105-6.

6. Haripriya $A$, Chang DF, Reena M, Shekhar M. Complication rates of phacoemulsification and manual small-incision cataract surgery at Aravind Eye Hospital. J Cataract Refract Surg. 2012;38:1360-9.

7. Greenberg PB, Tseng VL, Wu WC, Liu J, Jiang $\mathrm{L}$, Chen CK, et al. Prevalence and predictors of ocular complications associated with cataract surgery in United States veterans. Ophthalmology. 2011;118:507-14.
8. Dooley IJ, O'Brien PD. Subjective difficulty of each stage of phacoemulsification cataract surgery performed by basic surgical trainees. $J$ Cataract Refract Surg. 2006;32:604-8

9. Gogate PM. Small incision cataract surgery: Complications and mini-review Indian J Ophthalmol. 2009;57(1):45-9.

10. Burgansky Z, Isakov I, Avizemer H, Bartov E. Minimal astigmatism after sutureless planned extracapsular cataract extraction. I Cataract Refract Surg. 2002;28:499-503. 